DOI: https://doi.org/10.30525/978-9934-26-020-9-14

Ellana Molchanova

$P h D$ in Economics, Assosiate Professor

Kyiv National University of Trade and Economics

\title{
FORMATION OF A CRISIS MANAGEMENT TEAM
}

\section{Summary}

Today the issue of overcoming crises in companies becomes relevant. Most Ukrainian methods suggest forming anti-crisis teams at the time of the crisis. However, this proposal does not take into account the peculiarities of the psychological state of people at the time of the crisis. This statement is false. At the stage of creating a company, the management should already think about creating an anti-crisis team. We are not talking about crisis planning at the newly created enterprise. We are talking about the fact of the crisis under the influence of external or internal factors. Therefore, this research shows how American managers form a team and what are the functional responsibilities of each member team.

\section{Вступ}

Команда 3 управління антикризовими ситуаціями, також відома як команда 3 управління інцидентами або група реагування на корпоративні інциденти, готує організацію до реагування на потенційні надзвичайні ситуації. Ї̈̈ основним завданням $є$ координація діяльності компанії у разі настання кризової ситуації. У великих корпораціях може виникнути потреба сформувати декілька підкоманд, які координуватимуть свої дії з головною командою. У кожній команді призначається свій керівник. Але активація команди залежить від особливості протікання кризової ситуації.

Великим організаціям може знадобитися призначити провідну команду 3 управління кризовими ситуаціями та відповідні підгрупи (кожна 3 яких має свого керівника), які зосереджуються на конкретних робочих напрямах або географічних регіонах. Залежно від тяжкості та типу кризи, можливо, вам не доведеться активувати всі ролі в кожній кризі.

Членами кризової групи $\epsilon$, як правило, співробітники даної компанії, які обіймають інші посади в організації; менеджери 3 управління персоналом, керівники підрозділів, топ-менеджмент, представники зв'язків із громадськістю, керівники відділів зв'язку, маркетингу, юридичного відділу, IT тощо. Отже, розглянемо, як американські компанії формують антикризову команду. 


\section{Розділ 1. Завдання створення команди управління антикризовими ситуаціями}

Основна мета створення команди управління антикризовими ситуаціями - допомогти мінімізувати або, можливо, уникнути певної кризи, а в разі стихійного лиха якомога швидше відновити життєдіяльність компанії 3 мінімальними негативними наслідками. Обов'язки групи з урегулювання криз різняться залежно від фази. Фази відрізняють від звичних нам «фаз життєвого циклу компанії», зокрема етап планування, кризовий етап та етап післякризової ситуації.

Розглянемо ключові обв’язки команд. На етапі планування «команда» повинна:

1. проаналізувати потенційні ризики та вразливість організації;

2. обговорити зі стейкхолдерами їхні потреби та проблеми, які ймовірно можуть виникнути за певної кризової ситуації;

3. визначити наявні ресурси, необхідні для реагування під час кризи;

4. розробити детальний план ліквідації криз;

5. сформувати банк необхідної ресурсної бази;

6. навчити всіх працівників чітко виконувати покладені на них «ролі» в кризових ситуаціях. «Ролі» призначаються всім членам антикризової команди, а також майже всім співробітникам.

На фазі виникнення кризи команда відповідає за:

1. моніторинг та виявлення ранніх ознак надзвичайної ситуації;

2. оцінку впливу кризи на компанію;

3. активізацію системи реагування на кризу та системи кризових команд;

4. упровадження надзвичайних заходів та планів на випадок надзвичайних ситуацій;

5. повідомлення важливої інформації усім стейкхолдерам;

6. організацію підтримки (перша допомога, ресурси для психічного здоров'я та харчування);

7. підтримку морального духу;

8. узгодження з топ-менеджментом.

Після кризової ситуації команда повинна:

1. переглянути всі рішення та проаналізувати їх. Уникайте звинувачень, не допускайте ситуації, коли члени команди можуть відчути провину за прийняті рішення в стресових ситуаціях;

2. переглянути план антикризового управління на основі здобутого досвіду;

3. поповнити необхідні ресурси;

4. повідомити про всі зміни стейкхолдерів;

5. проводити додаткове навчання відповідно до внесених змін;

6. оновити антикризовий план та відповідні протоколи активації.

Команда антикризового управління, головним чином, зосереджена на:

1. виявленні ранніх ознак кризи; 
2. визначенні проблемних зон;

3. обговоренні віч-на-віч зі співробітниками про підозри у настанні кризових ситуацій;

4. підготовці плану врегулювання криз;

5. мотивації співробітників щодо злагодженої роботи на оптимістичних нотах. Не дозволяти людям утрачати надію та панікувати;

6. підготовці до майбутніх кризових ситуацій.

Процес формування команди повинен починатися 3 призначення керівника команди з антикризового управління. Керівник повинен бути як формальним, так і неформальним лідером. Він вступає у свої повноваження одночасно 3 командою за активації відповідних протоколів. Отже, ми визначили, які ключові обв'язки покладаються на команду. Наступним кроком під час планування антикризового плану $\epsilon$ призначення «ролей» кожному члену команди.

Члени команди повинні мати досвід роботи у сфері комунікацій, фінансів, адміністративних та операційних питань тощо. Подумайте про призначення одного члена команди для координації питань із топменеджментом. Бажано не залучати представників топ-менеджменту до команди 3 антикризового регулювання, оскільки останні можуть виявитися необ'єктивними під час прийняття певних питань. Окрім того, рішення про призначення ролей повинно грунтуватися на підставі розмірів компанії та географії іiі представництв. У великій команді 3 управління кризисними ситуаціями людина може відповідати за кожну сферу відповідальності, але членам менших команд можуть відводитися декілька ролей. Як правило, співробітники $є$ професіоналами в одній сфері, де вони зазвичай працюють, саме тому вони передають свої оперативні знання команді з управління кризисними ситуаціями.

\section{Розділ 2. Структура команди управління антикризовими ситуаціями}

У структурі будь-якої організації певні відділи вже працюють як частина команди. В умовах настання кризи ця команда стає підгрупою групи з управління кризисними ситуаціями та звітує перед призначеним членом команди. Наприклад, IT-відділи, як правило, мають групу, яка реагує на відключення або інші нагальні технічні проблеми як частину своєї звичайної роботи. У надзвичайній ситуації ця група активується як частина команди реагування на кризу.

Можемо запропонувати приблизну схему, яка відображає базову структуру (рис. 1).

Організаційна схема відображає базову структуру, в якій обов'язки розподілені між командою з управління антикризовими ситуаціями. Призначенням цієї команди може бути реагування на інциденти. У західній корпоративній практиці поняття «інцидент» використовують у разі настання природних або техногенних ситуацій, тому обов'язковим 
членом команди повинен бути начальник служби безпеки. Система управління інцидентами - це модель антикризового управління, яка розпочалася в уряді та поширилася на приватний сектор. Це практична модель, яку розробили пожежники Каліфорнії. Члени команди були поділені на чотири підкоманди за регіональним принципом. Це пов'язано з різними ландшафтними умовами (гори, пустеля, ліси), а також розмірами території. Сьогодні ця модель $є$ обов'язковою для всіх державних структур, садочків, шкіл та університетів у разі пожежі.

Кожна компанія під себе адаптує цю модель на випадок інших форм інцидентів. Відповідно до цієї моделі, членів команди також можуть поділити на підгрупи або сформувати окремі підкоманди. Підкоманди мають своїх керівників і відповідають за операційну діяльність, планування та розвідку, логістику та фінанси тощо. Розглянемо приблизну сферу відповідальності кожної підкоманди.

Підгрупа/команда 1 «менеджмент» може бути відповідальною за такі напрями:

1. управління загальним реагуванням на кризу;

2. визначення пріоритетів та цілей;

3. управління підконтрольних груп;

4. отримання ресурсів;

5. координація з топ-менеджментом;

6. вирішення суперечок та конфліктів між співробітниками.

До складу такої команди обов'язково входять прессекретар, начальник служби охорони праці та координатор (узгодження дій із топменеджерами).

Підгрупа/команда 2 «виробництво» може бути відповідальною за такі напрями:

1) забезпечення виконання тактичних цілей компанії під час кризи;

2) ідентифікація початкових утрат/збитків;

3) контроль над реакцією на кризу;

4) встановлення контролю над ситуацією;

5) складання звітів про поточний стан справ;

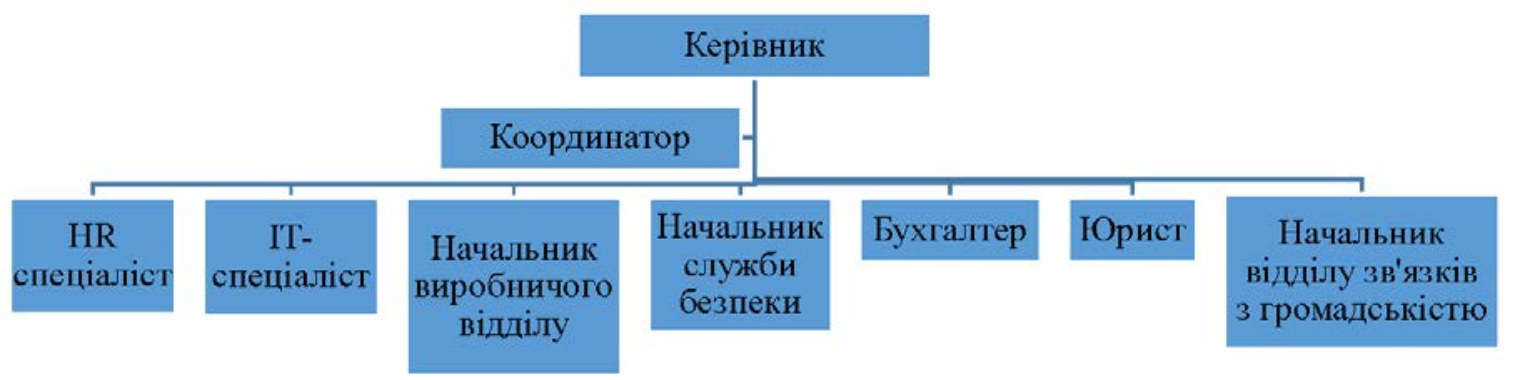

Рис. 1. Оріснтовна схема структури команди управлінням кризисними ситуаціями 
6) відновлення безперебійної діяльності компанії/виробництва.

Під час реалізації зазначених напрямів повинні також бути включені безпекові компоненти та IT.

Підгрупа/команда 3 «планування та прогнозування» може бути відповідальною за такі напрями:

- збір, аналіз та обмін інформацією про вплив кризи на діяльність підприємства/розгортання кризи;

- оцінку звіту про стан справ;

- формулювання рекомендацій щодо подальших дій.

Також слід залучити персонал для забезпечення безперервності бізнесу, корпоративної комунікації, правових взаємовідносин, взаємовідносин з інвесторами та іншими стейкхолдерами.

Підгрупа/команда 4 «логістика» може бути відповідальною за підтримку потреби співробітників (ресурси, їжа, притулок, транспорт, медичне обслуговування тощо).

До складу команди можуть бути включені представники відділу кадрів, відділу подорожей, служб переговорів та програми допомоги працівникам.

Підгрупа/команда 5 «фінансисти» може бути відповідальною за:

1) трекінг та документування всіх поточних та додаткових витрат;

2) обробку нарахувань заробітної плати, екстрених замовлень, потреб у готівці та грошах на карткових рахунках. У період кризи не рекомендують затримувати заробітну плату;

3) узгодження страхових внесків та компенсаційних виплат працівникам;

4) надання адміністративної підтримки.

Команда має включати представників відділів фінансів, ризику, страхування, фонду оплати праці, казначейства та закупівель.

Можемо побудувати шаблон, як формувати команду з управління антикризовими ситуаціями в рамках цієї системи. Одним із програмних продуктів $є$ Smartsheet [7]. Зручна для використання платформа, яка дає змогу виконати поставлені цілі. Ми призначаємо посади, членів команди та ролі. У програмі ролі виглядають як коротке поле на 500 символів. Однак цей опис - коротка посадова інструкція. Отже, до кожної посади слід написати інструкцію та призначити ролі кожному члену команди. I обов'язково визначте заступника або альтернативну персону для кожної ролі на випадок, якщо член команди перебуває у відпустці.

\section{Розділ 3. Призначення ролей членам групи 3 управління кризисними ситуаціями}

Керівник - основна ключова роль у всьому процесі. Керівники повинні мати повний контроль над працівниками. Слід усе тримати на пульсі, знати та розумітися, що відбувається навколо. Будь-яке питання, яким нехтували на початковому етапі, може бути головним питанням 
пізніше. Проблеми повинні бути вирішені негайно. Не слід ігнорувати навіть незначні проблеми або чекати, поки хтось інший проявить ініціативу. Будь-яка проблема, залишена без уваги, може призвести до кризи та великих заворушень пізніше.

На робочому місці слід бути пильним. Керівник повинен мати можливість відчувати ранні ознаки кризи та застерегти працівників від негативних наслідків. Його обов'язок - ужити запобіжних заходів, щоб уникнути надзвичайної ситуації. Лідер повинен передбачити кризу. Такий етап також називається виявленням сигналу.

Керівнику слід частіше взаємодіяти 3 працівниками, щоб з'явилося відчуття підтримки. Проведіть/організуйте для співробітників тренінги 3 управління кризисними ситуаціями.

Навчиться приймати швидкі рішення. Переконайтеся, що всі на робочому місці добре поінформовані про надзвичайні ситуації. Визначте важливі процеси та системи, які повинні продовжувати функціонувати для безперебійної роботи організації. Розробіть альтернативні плани 3 достовірною та точною інформацією. Не давайте змоги негативним емоціям розповсюджуватися в організації. Мотивуйте працівників вірити у себе та компанію. Важливо довіряти один одному під час кризових ситуацій. Уживайте жорстких заходів проти тих, хто поширює чутки та намагається заплямувати імідж організації. Не уникайте стейкхолдерів та представників засобів масової інформації: ігнорування може погіршити ситуацію. Розвивайте міцні партнерські стосунки із зовнішніми стейкхолдерами. Будьте готові попросити про допомогу.

Керівник повинен показувати приклад, бути міцною опорою для членів команди. Вони повинні мати можливість звернутися до керівника, вміти ризикувати, працювати наполегливо, добре адаптуватися до змін та нових ситуацій.

Коли організація вийшла 3 кризи, обов'язок керівника - поділитися отриманим досвідом із метою уникнення помилок у майбутньому.

Отже, керівник групи 3 урегулювання криз має достатньо повноважень та контролює кризове планування, реагування, постійно докладає зусиль і приймає важливі рішення. Щоб лідер був ефективним, топ-менеджмент, рада директорів тощо повинні повністю підтримувати лідера у цій ролі, його рішення. Таким чином, роль антикризового менеджера існує частково поза затвердженою організаційною ієрархією.

Менеджер з реагування на кризи, як правило, не з C-suite, має основну владу щодо прийняття рішень під час надзвичайних ситуацій і може давати вказівки начальству. Керівники повинні надати такі повноваження керівнику кризових ситуацій, щоб пришвидшити реагування на надзвичайні ситуації. В іншому разі повторне здогадування та надмірне управління С-пакетом можуть заглушити кризові зусилля. 
Якщо команда 3 управління антикризовими ситуаціями не має призначеного за координацію зв'язку 3 топ-менеджментом, керівник кризової групи виконує цю функцію.

Роль керівника групи з антикризового регулювання полягає у тому, щоб:

1. нести відповідальність за виконання плану антикризового управління;

2. створити ефективну кризову команду та переконатися, що всі готові;

3. моніторити ситуацію та зменшувати ризики;

4. оцінювати надзвичайну ситуацію;

5. повідомляти про кризу та активізувати протоколи антикризових планів;

6. перебрати на себе управління;

7. оцінювати варіанти, визначати проблеми та будувати стратегію;

8. забезпечувати безпеку працівників, компанії та стейкхолдерів;

9. регулярно інформувати керівництво про перебіг подій.

Команда 3 управління кризовими ситуаціями повинна розглядати всі аспекти кризи. Команда потребує членів, які мають досвід у різних галузях та сферах відповідальності.

Якщо в організації бракує людей із необхідними знаннями, на етапі планування подумайте, як можна заповнити ці прогалини. Ви можете призначити радників зі сторонніх компаній, які можуть надати додатковий персонал у надзвичайних ситуаціях, і погодитися з ними на офіційний план на випадок надзвичайних ситуацій, а також звернутися до зовнішніх експертів.

Основна команда управління кризовими ситуаціями включає такі ключові функції, як операційні, безпекові, IT, кадрові та комунікації.

Інші функції слід додавати у разі розширення напрямів прояву кризи. Хоча склад кожної команди різниться залежно від організації та загроз, 3 якими вона стикається, наведемо деякі додаткові ролі:

1. Менеджер служби безпеки: відповідає за оцінку безпеки реалізації антикризового плану та за безпеку «майданчика» під час кризи.

2. Прес-секретар/радник із питань громадських зв'язків: проводить брифінг зі ЗМІ, обробляє інформацію та формує стратегію обміну повідомленнями.

3. Менеджер із персоналу: веде інформацію про весь персонал, включаючи контактні дані та місцезнаходження поза робочим часом, а також відстежує, чи застраховані співробітники.

4. Керівник відділу охорони праці та навколишнього середовища зменшує ймовірність настання ризиків для здоров'я та безпеки персоналу, навколишного середовища. Окрім того, на нього покладається обов'язок проводити навчання для реагування в надзвичайних ситуаціях, оцінку збитків та здійснювати контроль.

5. Юрист: консультує компанію щодо юридичних та регуляторних зобов'язань та заходів щодо пом'якшення негативного впливу; перевіряє 
вихідну інформацію, готує всіх, хто пройшов співбесіду із зовнішнім органом та керує обміном конфіденційною інформацією.

6. Менеджер командного центру: відповідає за обслуговування командного центру. Його основна функція - забезпечити команду всім необхідним у командному центрі (обладнання, витратні матеріали тощо).

7. Менеджер з операційної діяльності: надає інформацію про те, як зупинити та відновити виробництво в надзвичайних ситуаціях, а також координує дії персоналу щодо відновлення виробництва.

8. Канцелярія: допомагає кризовій групі у розробленні документів, їх обробці та русі документів.

9. Менеджер 3 інформаційних технологій: надає IT-експертизу процесу планування та керує процесом під час IT-криз.

10. Економіст: під час кризового планування регулює першочерговість здійснення виплат та розрахунків, керує готівковими розрахунками та виплатам по кредитних картках, вирішує, чи буде затримуватися фінансова звітність, інформує страхові компанії та збирає необхідну документацію.

11. Представник структурного підрозділу: розробляє план антикризових заходів у своєму підрозділі, у разі потреби може залучити додатковий персонал.

12. Фахівці з «вузьких» питань: залежно від типу організації та за необхідності розробляє антикризові заходи.

Побудуємо приблизну ієрархічну структуру.

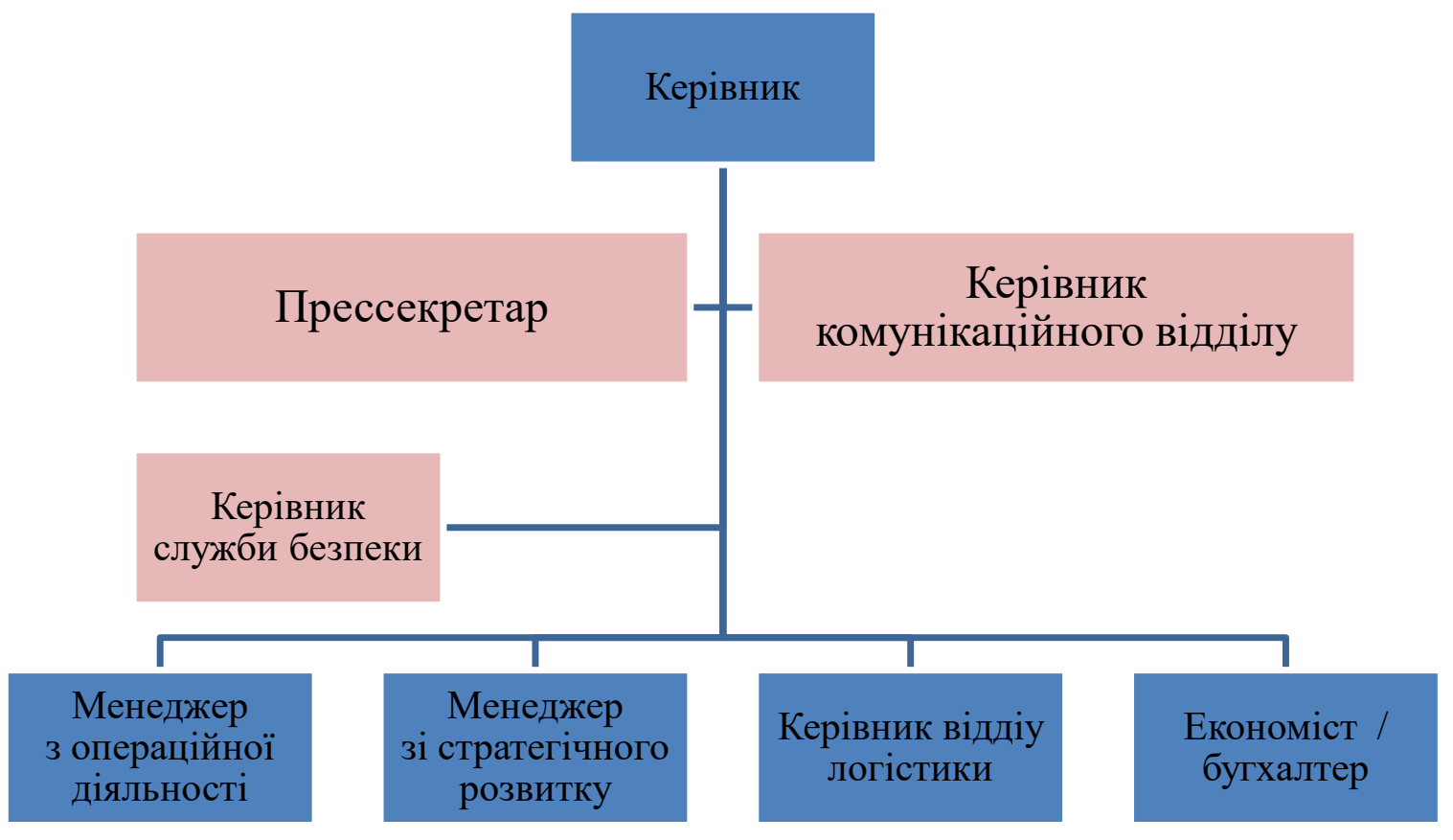

Рис. 2. Посднання ролей із ланцюжком команд в ісрархічній структурі антикризової команди 


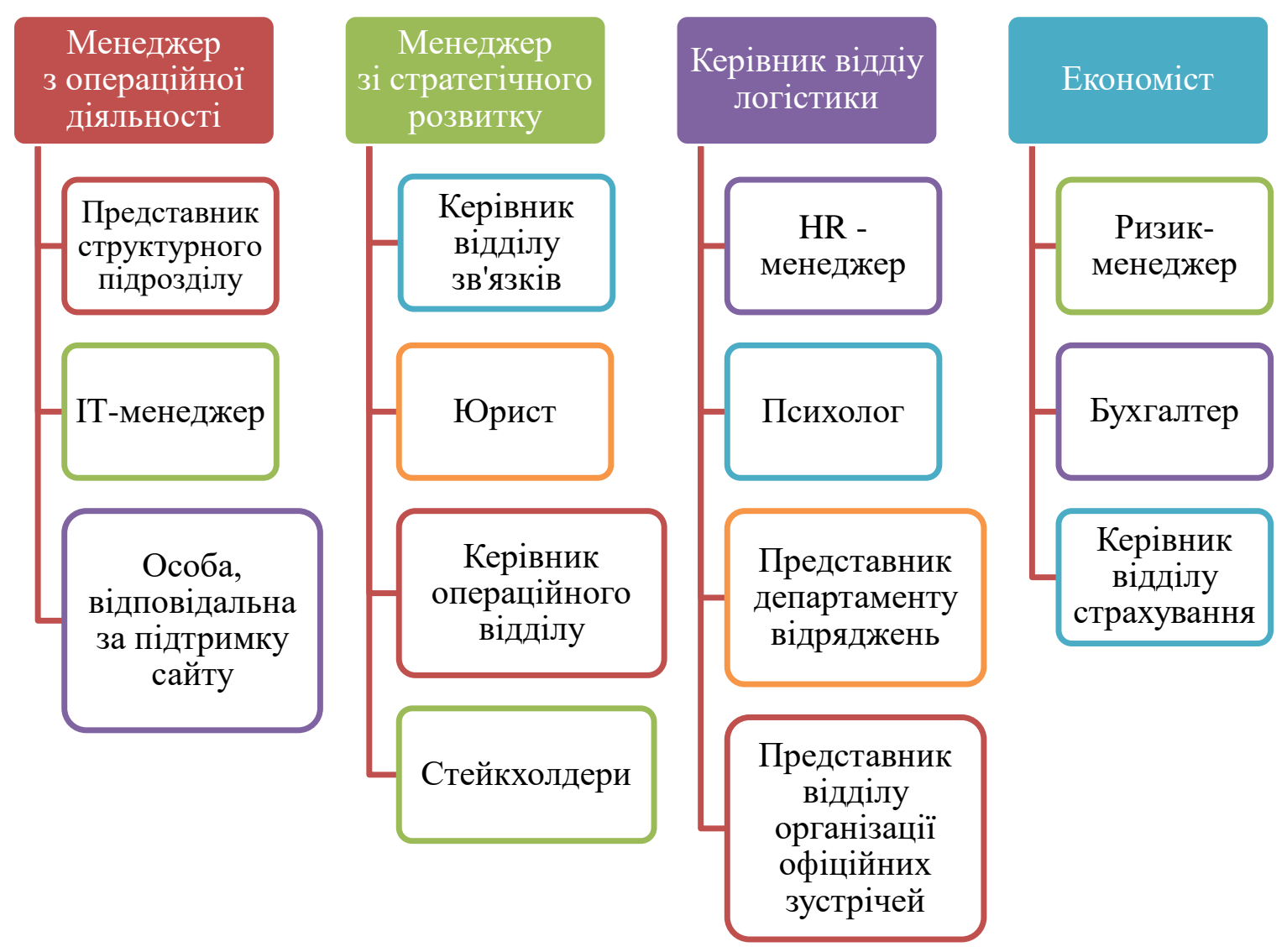

\section{Рис. 3. Посднання ролей із ланцюжком команд}

Схема організації показує, як ці ролі поєднуються з ланцюжком команд в організації. Ця структура не застосовується у разі настання інцидентів. Зазначена структура не є обов'язковою і суттєво відрізняється від будьякої ієрархічної структури в українських компаніях. Побудова такої структури повинна грунтуватися на ефективності.

Ефективність реагування на кризу частково залежить від людей, які входять до складу команди. Члени команди повинні мати такі здібності:

1. розуміти загальну картину організації;

2. ефективно захищати свій відділ або зону відповідальності;

3. бути комунікабельним;

4. бути здатним працювати в стресових ситуаціях, витримувати тиск;

5. думати швидко та аналітично.

Керівник групи з управління антикризовими ситуаціями повинен мати усі вищезазначені атрибути, а також:

1. бути сильним лідером;

2. приймати рішення швидко та ефективно;

3. поважати колег та керівництво;

4. бути багатозадачним;

5. уміти долати міжособистісні конфлікти;

6. бути ефективним делегатом. 
Генеральний директор або президент компанії дуже рідко очолюють антикризову групу або входить до ії складу. Натомість його завдання стратегічний розвиток. Генеральний директор або президент компанії мають чотири основні стратегічні обов'язки в кризових ситуаціях:

1. здійснення прямого стратегічного планування;

2. нагляд за фінансовою стратегією та надзвичайними витратами;

3. управління взаємовідносинами 3 працівниками, інвесторами, клієнтами та державними регуляторами;

4. виконання обов'язків прессекретаря у разі застосування теорії «вибачень» відповідно до рекомендацій керівника відділу зав'язків із громадськістю.

Перша зустріч команди повинна відбуватися після активації протоколів із «мозковим штурмом» - розуміння проблемної ситуацій. Після формування попереднього висновку про стан справ команда розподіляє свій функціонал відповідно до визначених проблем. На даному етапі головне, щоб кожен член команди розумів причини настання кризи, поточні процеси й як їх можна відновити/поліпшити/забезпечити безперервне функціонування організації.

Важливо визначити пріоритети питань. Ранжуйте проблеми відповідно до їхнього впливу на працівників та організацію. Команда управління кризисними ситуаціями повинна працювати 3 іншими співробітниками на спільній платформі, обговорювати переважаючі проблеми, приймати пропозиції один одного та досягати прийнятних для всіх планів. Найкращий спосіб - проведення анкетування. Усі співробітники компанії повинні прийняти участь та визначити, які загрози вони вважають найбільш суттєвими для забезпечення нормального виконання своїх функціональних обов'язків. Це вам допоможе створити ранжир [8].

Переконайтеся, що у вас $\epsilon$ точна інформація. Ще раз перевірте свою інформацію перед завершенням плану.

Негайно реалізуйте плани щодо результатів. Час від часу потрібно приймати належний відгук.

Команда 3 управління кризовими ситуаціями допомагає організації зробити правильний крок у потрібний час та допомогти подолати критичні ситуації.

Тоді вже можемо активувати протоколи та певні команди. Але для цього слід розробити посадові інструкції. Кожний член команди повинен знати свій функціонал.

\section{Розділ 4. Контрольний список групи управління кризисними ситуаціями}

Коли ви починаєте антикризове планування, формування команди антикризового управління $є$ одним із найважливіших пріоритетів. Дотримуйтеся контрольного списку, щоб переконатися, що не 
пропустили жодного ключового кроку, оскільки цей етап створює основу для детального планування антикризових заходів. Контрольний список ви також зможете створити в Smartsheet, а також установити лінки з усією інформацією, яку ви внесете в програму [7].

Приблизний контрольний список із планування роботи 3 антикризових ситуацій може виглядати так (табл. 1).

Таблиця 1

\section{Контрольний список із планування роботи з кризових ситуацій}

\begin{tabular}{|c|c|c|}
\hline & Кроки / ролі & Примітка \\
\hline 1. & Призначте менеджера антикризової групи та заступника & \\
\hline 2. & $\begin{array}{l}\text { Із керівником кризової групи та будь-якими зовнішніми } \\
\text { радниками/експертами визначте необхідні ролі в команді та } \\
\text { напишіть детальні функціональні обов'язків членів команди }\end{array}$ & \\
\hline 3. & $\begin{array}{l}\text { Призначте «ролі» речнику, начальнику служби безпеки та } \\
\text { зв'язку, а також заступникам. (Заступником не повинен бути } \\
\text { той, хто виконує іншу основну роль.) }\end{array}$ & \\
\hline 4. & $\begin{array}{l}\text { В організаціях, які мають стратегічне та безпекове значення для } \\
\text { країни, призначте керівників розвідки та планування, операцій, } \\
\text { логістики та фінансів, а також їх заступників }\end{array}$ & \\
\hline 5. & $\begin{array}{l}\text { В інших організаціях призначте менеджерів із комунікацій, } \\
\text { охорони праці, безпеки та навколишнього середовища, юриста, } \\
\text { HR, IT, фінансиста, а також заступників }\end{array}$ & \\
\hline 6. & Перегляньте деталі ролей із кожним членом майбутньої команди & \\
\hline 7. & Повторіть процес для підрозділу & \\
\hline 8. & $\begin{array}{l}\text { Створіть контактну систему взаємодії для всіх членів команди } \\
\text { та їх заступників за допомогою резервних систем, } \\
\text { відпрацьовуйте свої плани* }\end{array}$ & \\
\hline 9. & $\begin{array}{l}\text { Дайте кожному учаснику картку розміру гаманця з ключовою } \\
\text { контактною інформацією команди. Зберігайте цю інформацію } \\
\text { також у хмарі }\end{array}$ & \\
\hline 10. & $\begin{array}{l}\text { Коли ваш план реагування антикризових заходів буде завер- } \\
\text { шений, заплануйте тренінги з командою принаймні раз на півроку }\end{array}$ & \\
\hline
\end{tabular}

* Приклади включають використання програм для сповіщень, телефонного дерева та текстових повідомлень

У контрольному списку групи управління кризисними ситуаціями перелічено ключові дії у разі настання кризи для кожного члена команди відповідно до їхньої ролі. Розроблений шаблон дає вам змогу налаштувати контрольний список i позначати елементи поетапно. Наведені табл. 2-5 застосовують компанії під час планування заходів у разі настання кризи. Усі вони розміщені на серверах компаній, як правило, у внутрішній мережі, з можливістю зовнішнього доступу. 
Контрольний список відповідального за активацію протоколу. Перше реагування (за ролями)

\begin{tabular}{|c|c|c|}
\hline & Кроки / ролі & Примітки \\
\hline 1. & Зателефонувати в екстрену службу & \\
\hline 2. & $\begin{array}{l}\text { Повідомити про надзвичайну ситуацію керівнику та керівництву } \\
\text { з антикризового регулювання вашої організації, як зазначено у } \\
\text { вашому плані (наприклад, гаряча лінія) }\end{array}$ & \\
\hline 3. & Зібрати команду реагування & \\
\hline 4. & Встановити канали зв'язку & \\
\hline 5. & $\begin{array}{l}\text { Попросити працівників зв'язатися зі своїми сім’ями та } \\
\text { повідомити, що вони в безпеці }\end{array}$ & \\
\hline 6. & $\begin{array}{l}\text { Не дозволяти свідкам чи винуватцям кризової ситуації розмовляти } \\
3 \text { правоохоронними органами без юридичної консультації }\end{array}$ & \\
\hline 7. & Не заважати нічому, що може стати доказовою базою & \\
\hline 8. & $\begin{array}{l}\text { Заблокувати вхід на сайт, особливо якщо криза порушила роботу. } \\
\text { Відправити всіх співробітників, які не є членами антикризової } \\
\text { команди або не можуть допомогти у відновленні життєдіяльності } \\
\text { компанії, додому та дати їм указівки щодо подальших дій }\end{array}$ & \\
\hline 9. & $\begin{array}{l}\text { Якщо криза привернула увагу 3МІ, відповідайте на запити корот- } \\
\text { кою, стандартною відповіддю: «Я (ім’я) та я (назва) (назва компа- } \\
\text { нії). Цей інцидент стався короткий час тому, і на разі ми не можемо } \\
\text { відповісти на ваші запитання. Ми надамо додаткову інформацію о } \\
\text { (час). До цього часу нам потрібно зосередитися на події» }\end{array}$ & \\
\hline
\end{tabular}

Таблиця 3

\section{Контрольний список керівника антикризової групи. Перше реагування (за ролями)}

\section{Кроки / ролі}

\section{Примітки}

«Активувати» основних членів команди 3 управління антикризовими ситуаціями та повідомити про це керівництво вищого рівня

1. 3'ясувати всі наявні факти про надзвичайну ситуацію: де, коли та як це сталося, які люди були задіяні, їх місцезнаходження тощо

2. Визначити стан задіяної шкоди від кризи та вжити необхідні

2. заходи для iї стабілізації

3. Зателефонувати експерту, який потрібен для розв'язання першочер-

3. гових завдань на основі ваших знань про ситуацію на даний момент

4. Активувати командний центр

5. Оцінити ризик вторинних криз, наприклад яка екологічна шкода в 5. результаті вибуху турбіни

6. Налаштувати лінії зв’язку з місцевою владою та особами, які 6. першими реагують у разі настання ситуації

Установити графік і процес оновлень, таких як конференц-дзвінки

7. в певний час, і розподілити номери телефонів серед усіх членів антикризової команди. 
Менеджер з безпеки повинен здійснювати постійну координацію 3 керівником групи антикризового регулювання.

Таблиця 4

\section{Контрольний список менеджера $з$ безпеки. Перше реагування (за ролями)}

\begin{tabular}{|l|l|l|}
\hline 1. & Здійснювати координацію дій із керівником антикризової групи & Примітки \\
\hline 2. & $\begin{array}{l}\text { Дізнатися імена працівників, які постраждали або загинули. } \\
\text { Повідомити членів родини }\end{array}$ & \\
\hline 3. & Сформувати список усіх, хто став свідком інциденту \\
\hline 4. & Зробити нотатки цих співбесід у журналі подій & \\
\hline 5. & $\begin{array}{l}\text { Організувати графік здачі аналізів на виявлення наркотичного чи } \\
\text { алкогольного сп’яніння }\end{array}$ & \\
\hline 6. & $\begin{array}{l}\text { Призначити співробітника компанії залишатися на чергуванні в } \\
\text { лікарні до прибутя членів родини або контактної особи }\end{array}$ & \\
\hline 7. & $\begin{array}{l}\text { Розслідувати інциденти, задокументувавши ситуацію з додаванням } \\
\text { фотографій, відео тощо }\end{array}$ & \\
\hline 8. & $\begin{array}{l}\text { У разі настання нещасного випадку або загибелі субпідрядника } \\
\text { зв'язатися з його роботодавцем }\end{array}$ & \\
\hline 9. & $\begin{array}{l}\text { Повідомити громаду/місцеві органи влади у разі заподіяння шкоди } \\
\text { місцевому населенню }\end{array}$ & \\
\hline
\end{tabular}

Таблиця 5

\section{Контрольний список прес-секретаря. Перше реагування (за ролями)}

\begin{tabular}{|c|c|c|}
\hline & Кроки / ролі & Примітки \\
\hline 1. & $\begin{array}{l}\text { Дізнатися про всі наявні факти про кризу. Скласти відповідну } \\
\text { довідкову інформацію: виробнича потужність, обсяг виробництва } \\
\text { продукції, історія розвитку компанії, кількість працівників, } \\
\text { іміджеві боки тощо }\end{array}$ & \\
\hline 2. & $\begin{array}{l}\text { Підготувати заяву для ЗМІ та працювати з виконавчим органом } \\
\text { для отримання схвалення. Підготувати інформацію для } \\
\text { розміщення на офіційній сторінці компанії та в соцмережах }\end{array}$ & \\
\hline 3. & Встановити/активувати номер телефону для запитів із боку преси & \\
\hline 4. & $\begin{array}{l}\text { Призначити помічника для відповідей на дзвінки. Сформувати } \\
\text { «журнал» реєстрації дзвінків та встановлення пріоритетності } \\
\text { дзвінків і прийому повідомлень. Забезпечити постійне оновлення } \\
\text { інформації на сайті для зменшення звернення громадян }\end{array}$ & \\
\hline 5. & $\begin{array}{l}\text { Розробити та затвердити графік брифінгів, а також оприлюднення } \\
\text { цієї інформації }\end{array}$ & \\
\hline 6. & Підготувати приблизні відповіді на можливі запитання & \\
\hline
\end{tabular}


Контрольний список виконавчого директора. Перше реагування (за ролями)

\begin{tabular}{|c|c|c|}
\hline & Кроки / ролі & Примітки \\
\hline 1. & Зв’язатися з вищим керівництвом та поінформувати про хід справи & \\
\hline 2. & $\begin{array}{l}\text { Повідомити стейкхолдерів, які постраждали від надзвичайної } \\
\text { ситуації, та спільно з вищим керівництвом визначити стратегічні дії }\end{array}$ & \\
\hline 3. & $\begin{array}{l}\text { Координація } 3 \text { персоналом із питань консультування та інших } \\
\text { ресурсів }\end{array}$ & \\
\hline 4. & Активувати систему зв'язку працівників для надзвичайних ситуацій & \\
\hline 5. & Стежити за висвітленням у ЗМІ & \\
\hline 6. & $\begin{array}{l}\text { Проконсультуйтеся з керівництвом щодо заяв у ЗМІ та того, чи } \\
\text { настільки серйозний інцидент, щоб гарантувати найвищу } \\
\text { посадову особу, яка виконує обов'язки речника }\end{array}$ & \\
\hline 7. & Попрацюйте з юристом для виявлення та ескалації зобов’язань & \\
\hline 8. & $\begin{array}{l}\text { Постійно інформуйте керівництво про смерть та статус } \\
\text { постраждалих та обговорюйте, чи телефонувати чи відвідувати }\end{array}$ & \\
\hline
\end{tabular}

У разі настання кризової ситуації у відокремлених структурних підрозділах сформуйте команду в кожному підрозділі. Інформацію про членів команди слід оприлюднити на сайті. Слід пам'ятати, що кожна команда у цій моделі несе відповідальність за реагування у разі настання конкретної кризи.

\section{Висновки}

Організаційні проблеми можуть перешкодити роботі з антикризовою командою. Ефективність вашої реакції на кризу значною мірою буде залежати від корпоративної культури організації, яка формується керівництвом. Команда має бути сформована 3 однодумців, які відчувають підтримку керівництва. У разі заперечення настання кризи або вразливості компанії до певних обставин із боку керівництва ефективність запланованих заходів зводиться до нуля. Іноді це відображає політичну кризу в компанії: опір аналізу вразливості та слабких місць. Ще однією проблемою є впевненість, що страхування зробить антикризове планування менш необхідним. Або думка про те, що криза омине компанію.

На жаль, сучасне невизначене економічне середовище настільки мінливе, що передбачити всі можливі ризики стає важче, тому слід постійно монітори та аналізувати чинники, які можуть спричинити кризу в компанії.

\section{References:}

1. Fischbacher-Smith D. Crisis Management Teams: Issues in the Management of Operational Crises. URL: https://www.researchgate.net/publication/240233170_Crisis_ Management_Teams_Issues_in_the_Management_of_Operational_Crises 
2. Stanley J. Smits, Niveen Ezzat Ally «Thinking the unthinkable» - leadership's role in creating behavioral readiness for crisis management. URL: https://www.emerald.com/ insight/content/doi/10.1108/eb046448/full/html?skipTracking=true

3. Mikušová M., Horváthová P. Prepared for a crisis? Basic elements of crisis management in an organization. URL: https://www.tandfonline.com/doi/full/10.1080/ 1331677X.2019.1640625

4. Jobidon M-E., Turcotte I., Aubé C. Role Variability in Self-Organizing Teams Working in Crisis. URL: https://journals.sagepub.com/doi/abs/10.1177/1046496416676892 ?journalCode=sgrd

5. Athamneh S. HR Planning for Crisis Management. URL: https://www.intechopen.com/ books/human-resource-planning-for-the-21st-century/hr-planning-for-crisis-management

6. Pearson C., Mitroff I. From crisis prone to crisis prepared: a framework for crisis management. URL: https://journals.aom.org/doi/10.5465/ame.1993.9409142058

7. Smartsheet. URL: https://www.smartsheet.com/platform/capabilities\#dashboards

8. Smartsheet. URL: https://app.smartsheet.com/sheets/R3QH4p9QHJhW2X2P3cVHh MQx2Wfvm3cFJppPvC1?view=grid 